\title{
TASP1 wt Allele
}

National Cancer Institute

\section{Source}

National Cancer Institute. TASP1 wt Allele. NCI Thesaurus. Code C102895.

Human TASP1 wild-type allele is located in the vicinity of 20p12.1 and is approximately $373 \mathrm{~kb}$ in length. This allele, which encodes threonine aspartase 1 protein, is involved in proteolysis. 